\title{
Promote cultural development to strengthen the accounting occupation moral construction
}

\author{
Zhongmin Liu \\ The Computer Department, Qinhuangdao College of Northeast Petroleum University, \\ Qinhuangdao, HeBei, 066004, China \\ 1473696721@qq.com
}

\begin{abstract}
- accounting culture as a new way of thinking, is reflected in people 's accounting practice, however, with the deepening of China's economic development, reform and opening up and the increasing trend of global economic integration enhancement, great changes have taken place in the accounting environment, there is an urgent need to strengthen the integrity and moral construction of accounting, so as to promote the development of China accounting culture.
\end{abstract}

Keyword-accounting culture;occupation moral construction;internal control;accounting culture development

Accounting culture is composed of material culture, system culture accounting accounting accounting culture, the three part. Material culture is a set of accounting refers to the accounting work, accounting system; culture is the accountant occupation morals, values, behavior and system constraints; accounting refers to accounting personnel's spiritual culture, behavior culture, cultural heart.

In recent years, as the development of the social economy, driven by interests, forcing the accounting staff are facing severe test in the accounting integrity and occupation morality etc.. Business integrity and occupation moral issues, increasingly become the focus of public attention. The government and regulators gradually formed a consensus : the dynamic of the market economy to build healthy, must respect the principle of good faith. The lack of credibility, the cost of economic operation will be extremely expensive, or even impossible to run. In a fraud and fraud in society, the weak is not fair, honest is the most vulnerable. Therefore, in order to promote the development of culture, we must strengthen the construction of accounting honesty and occupation moral.

\section{CARRY OUT A COMPREHENSIVE ACCOUNTING OCCUPATION MORAL EDUCATION}

China's overall, the vast majority of accounting personnel and related to the leadership of the occupation attitude is correct, the higher occupation moral quality. In the provinces, our country city and Industry Award in recognition of accounting advanced collective and advanced workers, their glorious deeds of the morality, is the accounting personnel in our country embodies the good occupation moral noble and specific interpretation, but also offer an own strength to promote China's construction of accounting culture. Without their dedication, unknown to the public, be conscientious and do one's best work and labor, the development of China's accounting culture would not have made tremendous achievements today.

However, in the current market economy under the conditions of accounting occupation area, there are some accounting personnel in violation of occupation moral, know the law but break it, even the " law ", the accountant occupation morals are not the main reason behavior, driven and its formation is of interest. Accounting personnel through manufacturing and providing false accounting information to get the benefits, such as through the virtual account profit for incentives. In order to make the construction of accounting culture in China to get rid of this awkward situation, we must carry out comprehensive accounting occupation moral education and construction. We can see from the following aspects:

First of all, the need for the concept of accounting education. On the understanding and mastering the knowledge of accounting basis of accounting concepts, must also have a profound understanding of. Renewal of ideas is the premise of the construction of accounting culture, we should focus on the theme of accounting accounting culture, and society in the new era of relations, psychology, anthropology, public relations, to carry out the theoretical study, to establish a new concept of accounting culture by means of publicity and, stimulate interest in accounting culture, accelerate the construction of accounting culture the pace of. However, as a qualified accounting personnel, only theoretical knowledge is not enough, should also have the ability to apply knowledge in practice, to solve practical problems, processing and analyzing information. Including: ( 1 ) general ability, namely knowledge, communication expression ability and the ability to use information technology; ( 2 ) the professional knowledge, namely organizational and business knowledge, accounting and related knowledge; ( 3 ) professional ability, namely the solid technology, skills, analysis and problem solving.

Secondly, after engaged in accounting work for some time in the accounting personnel, not only to the continuing education for professional knowledge, education is to the accounting occupation moral. With the development of China's accounting system is ceaseless and perfect, the accounting personnel should adhere to lifelong learning, the ability to maintain and improve the technical knowledge and professional skills. To continue to break the old thinking, with new ideas and vision to grasp the trend of 
social development, to build up the knowledge and ability structure new knowledge economy. Only by continuously, system, regular system of continuing education, occupation, can be in accordance with the requirements of the accounting occupation moral, gradually completed from spontaneity to consciousness, from the outside to the inside, from passive to active, From Heteronomy to self-discipline behavior change, so that their morality to a new realm.

Finally is the social education. Through the exchange of learning and other excellent accounting personnel, and a variety of media publicity, discussion on accounting occupation moral, establish the typical positive, stimulate the accounting personnel in a wide range of social interpersonal atmosphere of shame and a sense of moral responsibility, to promote good or evil, the formation of accounting occupation moral support and incentive mechanism, improve the accounting occupation moral authority.

\section{IMPROVE THE ACCOUNTING LAW, STRENGTHEN CONSTRUCTION}

Market economy is legal economy, since the reform and opening up, with the economic reform and development to adapt to the requirements, the construction of China's accounting legal system has made considerable progress, issued the " accounting law ", " registered accountants act ", a major reform of accounting system, accounting management system, initially set up to " accounting law ", " registered accountants act " as the core content, and international coordination of accounting law system, greatly promoting the accounting legalization process. However, at present a few accounting personnel lack of legal concept, to the pursuit of self-interest, the loss of legal concept, at the very least defy the law, embarked on the path of crime. These illegal and criminal behavior while a minority accounting for personnel, but also reflects the urgency of strengthening the legal system construction of accounting under the new situation, the accounting personnel to strengthen legal concept construction, extensive publicity and education, popularization of legal knowledge, strengthen the legal liability of accounting personnel.

Accounting culture connotation of accounting culture is the most vivid, it reflects the accounting human character, language, appearance, style of work, communication etc.. The construction of accounting personnel to shape the good image of accounting behavior. Accounting personnel perform their duties on behalf of the state, unit, to exercise their rights, direct contact with many people, its image, to the country, enterprise reputation. The behavior of construction is the starting point and the foothold of the construction of accounting culture, is the ultimate objective of accounting culture to achieve. From the angle of the whole society, the construction of accounting culture to make the accounting personnel in the correct value guidance, improve their own quality and level of service, to win the respect of society, trust and support.

\section{III.THE ESTABLISHMENT OF INTERNAL CONTROL SYSTEM}

Internal control system is an important system of modern enterprise management, the basic norms and the enterprise internal financial management and accounting, a set of normative and perfect internal control system, can effectively to guarantee the legal truth, accounting information; improve the accuracy and reliability of accounting information, ensure the enterprise assets are the safe and effective, reasonable guarantee the normal business activities carried out, the correct evaluation of the economic efficiency of enterprises to improve the management level of enterprises. Therefore, an important way to control accounting fraud is to establish an internal control system scientifically and reasonably efficient and continue to improve, in the organization and personnel arrangement and strictly implement the " basic accounting standard " work, implement the job separation system, between the daily accounting business processing and accounting records management each link of the personnel division of science, clear responsibilities, the formation of both mutual cooperation and mutual supervision mechanism, restrict each other, so it can reduce the possible letter cheating.

\section{INTENSIFY THE CRACKDOWN ON VIOLATIONS OF ACCOUNTING OCCUPATION MORAL BEHAVIOR}

Nothing can be accomplished without norms and standards. For corruption, lawlessness, fail to report the facts or associate oneself with undesirable elements etc. phenomenon, in addition to administrative penalty must be in accordance with the provisions of, serious still can find out the legal liability of accounting personnel and relevant personnel. Increase the punishment on those who violate the law in height is an important part of the integrity of the building, to form a who trust in society, who will lose their livelihood depends on all of the situation. While in our country the accounting fraud punishment is not enough, although " about breaking accounting rules in terms of punishment accounting law ", but it is too general, implementation is not optimistic. Therefore, we should further standardize the accounting frauds punishment, it is necessary to perfect the legal system in order to " accounting law " as the center, to develop the implementation of the relevant rules and supporting legal system, to formulate and carry out the " cost " is much higher than the " cost of keeping " punishment system within the framework of the law, from the legislative level in the accounting counterfeiters harsh sentences or fines, the accounting credit for all eternity, as a warning to others.

In short, we should regard the construction of accounting culture in China in the perspective of development, solve the Chinese accounting reform and the specific accounting environment to adapt to all kinds of contradictions encountered. Modern accounting, accounting culture has been beyond the traditional calculation of 
culture and Book Culture, formed a kind of information culture and social service culture, accounting is influenced by the culture of this specific type of accounting. Accounting culture today pay more attention to the construction of material level, but often ignore the construction of accounting occupation moral level, occupation character and spirit culture. This situation need to change. Because the occupation character, too complex accounting culture often causes the accounting people is distorted, the integrity to utilitarianism. We want to make the accounting staff to recognize, and trustworthy as no passbook savings, can receive the " installment " effect in the future work and life, and the promise is like a pending loss of assets, is to pay the price sooner or later. Therefore, we should actively strengthen the construction of spiritual culture of accounting, adhere to the integrity of the building as the main line, the use of various forms of exploitation, development of accounting culture, so as to realize the contemporary accounting culture health and prosperity, the construction of Chinese accounting culture advanced, provide excellent service for the society.

\section{REFERENCE}

[1] Wu Shuipeng . Research on [M]. Chinese accounting theory in China financial and Economic Publishing House, December2000 .

[2] Chen Gong Meng. China's current accounting and financial problems [M]. World Book Inc, October1999 .

[3] Xiang Huaicheng. Accounting occupation moral [M]. people's publishing house, May2003.

[4]Yu Haibiao. A study on occupation morality [J]. accounting in China, October1996.

[5] micrograms. Socialist accounting occupation moral [M]. Economic Science Press, 1987. 